\title{
Fractionation and a-glucosidase Inhibitory Activity of Fractions from Garcinia hombroniana Pierre Leaves Extracts
}

\author{
Nita Triadisti", Rani Sauriasari, Berna Elya*
}

\section{Nita Triadisti*, Rani Sauriasari, Berna Elya*}

Faculty of Pharmacy, University of Indonesia, 16424, Depok, INDONESIA.

Correspondence

Nita Triadisti and Berna Elya

Faculty of Pharmacy, University of Indonesia, Depok 16424, INDONESIA.

Phone numbers : +62 87814381488 (Nita Triadisti) and +6281314161497 (Berna Elya)

E-mail: triadisti@gmail.com (Nita Triadisti ) and berna.elya@gmail.com (Berna Elya)

\section{History}

- Submission Date: 21-02-2017.

- Review completed: 07-04-2017

- Accepted Date: 03-05-2017

DOI : 10.5530/pj.2017.4.79

Article Available online

http://www.phcogj.com/v9/i4

\section{Copyright}

(c) 2017 Phcog.Net. This is an openaccess article distributed under the terms of the Creative Commons Attribution 4.0 International license.

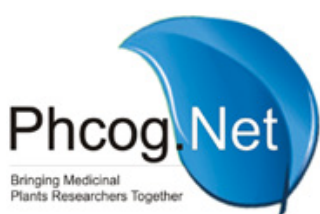

\begin{abstract}
Background: Diabetes mellitus become one of the biggest global health problems of the 21 st century. Type 2 diabetes play role for the majority of cases of diabetes worldwide which is characterized by the increase of postprandial blood glucose level. Maintaining postprandial glucose level through inhibition of $\alpha$-glucosidase is one of the essential strategies in the treatment of diabetes. Inhibitory effect of $\alpha$-glucosidase was commonly used to identify active compounds potentially to treat diabetes. Natural resources have potency as antidiabetic that can be used in diabetes treatment. Objective: The objective of the study is to separate active fraction in the crude extract of Garcinia hombroniana leaves to facilitate obtaining a pure biologically active compound as the $\alpha$-glucosidase inhibitor. Methods: Fractionation to separate active fraction was performed using column and thin layer chromatography methods while $\alpha$-glucosidase inhibitory activity assay was performed in vitro using spectrophotometric methods at $\lambda 400 \mathrm{~nm}$. Results: Ethyl acetate and methanol extract of $G$. hombroniana yielded 14 and 12 fractions, respectively. Two fractions with the higher percent inhibition compared to other factions are fraction 8 from ethyl acetate extract (FEA8) and fraction 3 from methanol extract (FM3). The IC ${ }_{50}$ values of FEA8, FM3 and acarbose are $16.370 \mu \mathrm{g} / \mathrm{mL}, 59.042 \mu \mathrm{g} / \mathrm{mL}$, and $39.534 \mu \mathrm{g} / \mathrm{mL}$ respectively. Conclusion: Fraction 8 from ethyl acetate extract of $G$. hombroniana leaves (FEA8) was separated and known in this study as the most bioactive $\alpha$-glucosidase inhibitor agent compared with another extract, fractions, and acarbose.
\end{abstract}

Key words: Diabetes mellitus, Fractionation, Column chromatography, Thin layer chromatography, $\alpha$-glucosidase.

\section{INTRODUCTION}

Diabetes mellitus becomes one of the biggest global health problems of the 21st century. International Diabetes Federation (IDF) analyzed that, by 2040 the global figure will grow to 642 million if nothing is done to respond the growing diabetes epidemic. ${ }^{1}$ WHO Global report on diabetes shows that since 1980 community is currently living with diabetes has risen from 180 to 422 million. ${ }^{2}$ Type 2 diabetes play role for the majority of cases of diabetes worldwide. Rising phenomenon in diabetes has become a critical concern that drives effort in searching for a new drug from natural resources to face this trend. Diabetes characterized by the increase of postprandial blood glucose level. The management of postprandial blood glucose level important in the treatment of diabetes. The a-glucosidase inhibitor is responsible for the degradation of carbohydrates, it slows down the degradation of carbohydrates by inhibiting the activity of a-glucosidase competitively, so postprandial blood glucose level can be decreased and the postprandial blood glucose level comes under control. $\alpha$-glucosidase inhibitors can be an alternative first line agent and provide several benefits, ${ }^{3}$ it has been recommended by American Association of Clinical Endocrinologists and Third Asia-Pacific Region Diabetes Treatment Guidelines as the first-line of treatment for lowering postprandial hyperglycemia. Their efficacy in lowering $\mathrm{HbAlc}$, and reducing post-meal blood sugars, make them suitable for use in type 2 diabetes., ${ }^{4,5}$ a-glucosidase inhibitors effective as monotherapy and polytherapy with other diabetes therapeutic agents. ${ }^{6}$

Natural resources have provided a good source of a wide variety of bioactive compounds from which we can develop new therapeutic agents. Many plants used in the treatment of diabetes, and from the study on various parts of plant, leaves are the most promising part for obtaining active compound. ${ }^{7,8}$ Indonesia is a mega-biodiversity country, which has a lot of potential medicinal plants to be developed as an active herbal ingredient or lead compound from plant materials for drug development. $\alpha$-glucosidase inhibitors that have been used clinically is voglibose, acarbose, and miglitol. Limited choice of a-glucosidase inhibitors has motivated research to get a new a-glucosidase inhibitors agents are expected to have better effectiveness.

a-glucosidase inhibitory activity assay of plants was conducted on Garcinia fruticosa Lauterb, Garcinia rigida Miq, Garcinia daedalanthera Pierre, Garcinia hombroniana Pierre, Garcinia kydia Roxb, and Garcinia bancana Miq and resulting that these extracts 
have $\alpha$-glucosidase inhibitory activity, ${ }^{9,10}$ but further studies to obtain the active fraction that has $\alpha$-glucosidase inhibition activity has not been done. The aim of the study is to separate active fraction in the crude extract of $G$. hombroniana leaves to facilitate obtaining a pure biologically active compound as the $\alpha$-glucosidase inhibitor.

\section{MATERIALS AND METHODS}

\section{Materials}

G. hombroniana Pierre leaves extracts were obtained from Laboratory of Photochemistry and Pharmacognosy, Faculty of Pharmacy, University of Indonesia, a-glucosidase from S. cerevisiae (Sigma-Aldrich, Singapore), substrate $p$-nitrophenyl- $\alpha$-D-glucopyranoside (Sigma-Aldrich, Singapore), Sodium hydroxide, Potassium dihydrogen phosphate (Merck), Sodium carbonate (Merck), Bovine serum albumin (Merck), Acarbose (SigmaAldrich, Singapore), Analytical grade acetone, ethyl acetate, chloroform, n-hexane, and methanol, Technical grade n-hexane, ethyl acetate, and methanol have been distilled, Silica gel (70-230 mesh) (Merck), TLC Plate (Silica gel 60 F254) (Merck).

\section{Fractionation of G. hombroniana Leaves Extract}

Fractionation extract of $G$. hombroniana ( $20 \mathrm{~g}$ ) was performed by column chromatography (diameter $4 \mathrm{~cm}$ and height $50 \mathrm{~cm})$. Silica gel $(70-230$ mesh) as the stationary phase prepared by mixing $300 \mathrm{~g}$ of silica gel and n-hexane was entered into the column. Combinations of solvents with increasing polarity were used as the mobile phase. The wet packing method was used in preparing the silica gel column. Extracts were prepared in a ceramic mortar by silica gel (70-230 mesh) in acetone and left to dry and then gently layered on top of the column. Elution process was performed with solvent gradient systems in polarity using $\mathrm{n}$-hexane, ethyl acetate, and methanol. Ratios of solvent combinations were sequentially used in the gradient elution; n-hexane: ethyl acetate 100:0, 90:10, 80:20, 70: 30, and so on until comparison 0: 100; and then ethyl acetate: methanol 100:0, 90:10, 80:20, 70: 30, and so on until comparison 0: 100. The eluted fractions were collected in aliquots of $100 \mathrm{ml}$ in a bottle. Fractions are then evaporated and tested using thin layer chromatography.

\section{Analytical Thin Layer Chromatography (TLC) and Pooling of Fractions}

Analytical TLC used a plate of silica gel $60 \mathrm{~F}_{254}$ (Merck). A plate of silica gel was cut out. With capillary pipe, a spot of the sample was applied on a plate about $1.0 \mathrm{~cm}$ from the edge. The plate was entered into a small chamber containing the solvent system and then viewed using UV lamp (Camag) to identify chromatogram pattern. The fraction that has the same chromatogram pattern then merged and tested its activity in inhibition enzyme $\alpha$-glucosidase. Potential fraction as the $\alpha$-glucosidase inhibitor was identified with analytical TLC (silica gel $60 \mathrm{~F}_{254}$ ) (Merck), using spray reagent ( $1 \%$ ethanolic solution of aluminum chloride and $10 \%$ methanolic solution of sulphuric acid ) and then be observed under UV light.

\section{Inhibition of a-glucosidase Assay}

The inhibition of $\alpha$-glucosidase was assessed using adopted method. ${ }^{11}$ A volume of $30 \mu \mathrm{l}$ of sample, $36 \mu \mathrm{L}$ of $0.1 \mathrm{M}$ phosphate buffer ( $\mathrm{pH}$ 6.8) and $17 \mu \mathrm{L}$ substrate $p$-nitrophenyl- $\alpha$-D-glucopyranoside at concentration of $4 \mathrm{mM}$ were put in 96 well microplate and then preincubated at $37^{\circ} \mathrm{C}$ for $5 \mathrm{~min}$. After preincubating at $37^{\circ} \mathrm{C}$ for 5 minutes, $17 \mu \mathrm{L}(0.08$ units $/ \mathrm{ml})$ $\alpha$-glucosidase was added and incubated at $37^{\circ} \mathrm{C}$ for 15 minutes to get the complete reaction. The reaction was stopped by adding $100 \mu \mathrm{L} \mathrm{Na}_{2} \mathrm{CO}_{3}$ $200 \mathrm{mM}$ into each well, and absorbance was measured at $400 \mathrm{~nm}$ by a microplate reader (Versamax ELISA Microplate Reader, USA). The $\mathrm{IC}_{50}$ value which defined as the concentration of the sample needed to inhibit $50 \%$ of $\alpha$-glucosidase activity in assay conditions, analyzed using GraphPad Prism.

\section{RESULTS}

Extracts' test results of $\alpha$-glucosidase inhibition, show that percent inhibition of $\mathrm{n}$-hexane extract is the lowest, so fractionation performed only on ethyl acetate and methanol extract of G.hombroniana (Table 1). Fractionation of ethyl acetate and methanol extract of G.hombroniana yielded 14 and 12 fractions, respectively (Table 2). Two fractions with the higher percent inhibition compared to other factions are fraction 8 from ethyl acetate extract (FEA8) and fraction 3 from methanol extract (FM3), their TLC profile is shown in Figure 1 and their percent inhibition in various concentrations shown in Table 3. FEA8 became the most

Table 1: $a$-glucosidase inhibition activity of extracts $(100 \mu \mathrm{g} / \mathrm{mL})$

\begin{tabular}{ccc}
\hline No. & Extract & Percent Inhibition (\%) \pm SEM \\
\hline 1. & n-Hexane & $6.343 \% \pm 1.624$ \\
2. & Ethyl acetate & $18.143 \% \pm 2.095$ \\
3. & Methanol & $22.677 \% \pm 1.156$
\end{tabular}

Data are mean \pm SEM or $\% \pm$ SEM for triplicate measurements.

Table 2: Weight, eluent of column and percent inhibition of the fractions $(100 \mu \mathrm{g} / \mathrm{mL})$

\begin{tabular}{|c|c|c|c|}
\hline Fraction & Weight (g) & Eluent of column & $\begin{array}{c}\text { Percent Inhibition (\%) } \\
\pm \text { SEM }\end{array}$ \\
\hline FEA1 & 0.219 & $H / E=9: 1$ & $15.500 \% \pm 2.562$ \\
\hline FEA2 & 0.284 & $H / E=8: 2$ & $22.223 \% \pm 0.445$ \\
\hline FEA3 & 0.362 & $H / E=8: 2$ & $12.090 \% \pm 3.387$ \\
\hline FEA4 & 1.919 & $H / E=8: 2$ & $8.913 \% \pm 0.673$ \\
\hline FEA5 & 5.098 & $H / E=8: 2-7: 3$ & $21.990 \% \pm 2.050$ \\
\hline FEA6 & 0.909 & $H / E=7: 3$ & $17.930 \% \pm 1.711$ \\
\hline FEA7 & 0.821 & $H / E=7: 3-6: 4$ & $17.603 \% \pm 1.375$ \\
\hline FEA8 & 0.734 & $H / E=5: 5$ & $71.057 \% \pm 1.178$ \\
\hline FEA9 & 0.599 & $H / E=4: 6-3: 7$ & $23.577 \% \pm 1.235$ \\
\hline FEA10 & 2.793 & $H / E=2: 8-\mathrm{E} / \mathrm{M}=9: 1$ & $26.657 \% \pm 0.930$ \\
\hline FEA11 & 1.412 & $\mathrm{E} / \mathrm{M}=9: 1-8: 2$ & $25.350 \% \pm 2.796$ \\
\hline FEA12 & 0.299 & $\mathrm{E} / \mathrm{M}=7: 3$ & $23.810 \% \pm 0.718$ \\
\hline FEA13 & 1.728 & $E / M=6: 4-2: 8$ & $20.403 \% \pm 0.678$ \\
\hline FEA14 & 1.424 & $E / M=2: 8-0: 10$ & $13.587 \% \pm 1.060$ \\
\hline FM1 & 0.074 & $H / E=8: 2$ & $23.953 \% \pm 0.479$ \\
\hline FM2 & 0.873 & $H / E=7: 3-2: 8$ & $15.173 \% \pm 0.415$ \\
\hline FM3 & 0.213 & $H / E=2: 8-\mathrm{E} / \mathrm{M}=9: 1$ & $30.263 \% \pm 0.991$ \\
\hline FM4 & 0.607 & $E / M=9: 1-8: 2$ & $20.300 \% \pm 1.571$ \\
\hline FM5 & 0.777 & $\mathrm{E} / \mathrm{M}=7: 3$ & $17.380 \% \pm 0.846$ \\
\hline FM6 & 2.246 & $E / M=6: 4-5: 5$ & $14.137 \% \pm 1.354$ \\
\hline FM7 & 1.889 & $E / M=5: 5-3: 7$ & $11.633 \% \pm 1.285$ \\
\hline FM8 & 1.119 & $E / M=2: 8-5: 5$ & $18.300 \% \pm 2.163$ \\
\hline FM9 & 1.661 & $E / M=4: 6$ & $19.477 \% \pm 0.529$ \\
\hline FM10 & 1.512 & $\mathrm{E} / \mathrm{M}=0: 10$ & $18.887 \% \pm 1.444$ \\
\hline FM11 & 1.480 & $\mathrm{E} / \mathrm{M}=0: 10$ & $9.150 \% \pm 1.960$ \\
\hline FM12 & 2.205 & $E / M=0: 10$ & $9.543 \% \pm 0.719$ \\
\hline
\end{tabular}

Description: $\mathrm{FEA}=$ fractions from extract ethylacetate, $\mathrm{FM}=$ fractions from extract methanol, $\mathrm{H}=\mathrm{n}$-Hexane, $\mathrm{E}=$ ethyl acetate, $\mathrm{M}$ : methanol.

Data are mean \pm SEM or $\% \pm$ SEM for triplicate measurements. 


\section{Table 3: Percent inhibition of FEA8 and FM3}

\begin{tabular}{ccc}
\hline No. & Concentration $(\mu \mathrm{g} / \mathrm{mL})$ & Percent Inhibition $(\%) \pm$ SEM \\
\hline & FEA8 & \\
1. & 1.5 & $32.087 \% \pm 3.588$ \\
2. & 4.5 & $33.200 \% \pm 2.166$ \\
3. & 10.5 & $47.380 \% \pm 1.158$ \\
4. & 56.25 & $79.290 \% \pm 1.370$ \\
5. & 75 & $82.003 \% \pm 1.185$ \\
& FM3 & \\
1. & 1.5 & $1.233 \% \pm 0.841$ \\
2. & 4.5 & $4.983 \% \pm 1.228$ \\
3. & 37.5 & $36.683 \% \pm 1.169$ \\
4. & 56.25 & $47.840 \% \pm 1.109$ \\
5. & 75 & $60.867 \% \pm 0.911$ \\
\hline
\end{tabular}

Data are mean \pm SEM or $\% \pm$ SEM for triplicate measurements.

Table 4: $\mathrm{IC}_{50}$ values of FEA8, FM3, and acarbose

\begin{tabular}{ccc}
\hline No. & Sample & $\mathrm{IC}_{50}(\mu \mathrm{g} / \mathrm{mL})$ \\
\hline 1. & FEA 8 & 16.370 \\
2. & FM3 & 59.042 \\
3. & Acarbose & 39.534 \\
\hline
\end{tabular}

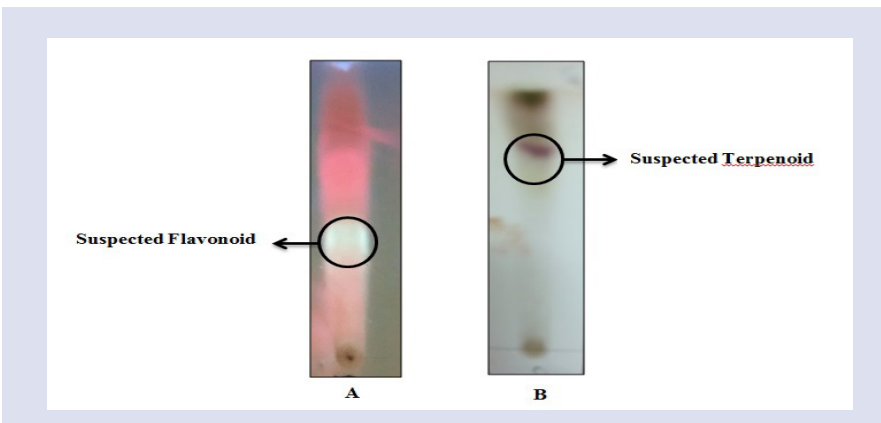

Figure 1: A.TLC Profile of FEA8 B. TLC Profile of FM3

bioactive fraction in $\alpha$-glucosidase inhibition activity. The $\mathrm{IC}_{50}$ values of FEA8, FM3, and acarbose as positive control are presented in Table 4.

\section{DISCUSSION}

This study was conducted in order to evaluate $\alpha$-glucosidase inhibitor potentials of fractions separated from extract of G.hombroniana leaves. Antidiabetic properties were determined in terms of the activity to inhibit $\alpha$-glucosidase. Inhibition of $\alpha$-glucosidase was exhibited to delay the degradation of carbohydrates. Therefore, $a$-glucosidase inhibitors have efficacy as therapeutic agents for the management of type 2 diabetes. ${ }^{12}$ Extracts' test results of $\alpha$-glucosidase inhibition show that percent inhibition of $\mathrm{n}$-hexane extract is the lowest, so fractionation performed only on methanol and ethyl acetate extract of G.hombroniana (Table 1). Methanol and ethyl acetate extract of G.hombroniana leaves yielded 14 and 12 fractions, respectively using column chromatography. Each fraction produced was evaluated in an in vitro a-glucosidase inhibitory studies using microplate reader to facilitate selection of the bioactive fraction.

In vitro a-glucosidase inhibitory studies of fractions demonstrated that all samples had inhibitory activity (Table 2). Fraction 8 from ethyl acetate extract (FEA8) and fraction 3 from methanol extract (FM3) exhibited potency as better $\alpha$-glucosidase inhibitor compared to other fractions with percent inhibition $71.057 \% \pm 2.040$ and $30.263 \% \pm 1.716$, respectively. Percent inhibition of FEA 8 and FM3 in various concentrations shown in Table 3 . The highest inhibitory activity of samples was obtained from FEA8 fraction with $\mathrm{IC}_{50}$ value $16.370 \mathrm{ug} / \mathrm{mL}$. The $\mathrm{IC}_{50}$ value of FEA8 fraction was much smaller than the $\mathrm{IC}_{50}$ of acarbose as a positive control ( $\mathrm{IC}_{50}$ acarbose: $39.534 \mu \mathrm{g} / \mathrm{mL}$ ) (Table 4). It shows that FEA8 fraction inhibits the activity of $\alpha$-glucosidase better than acarbose in a smaller concentration. Assay of $\alpha$-glucosidase inhibition activity shows that fractions obtained have the higher potency than extract origin, it may because the increase in activity after fractionation may be as a result of separation the active ingredients from the nonactive fractions. The active fraction would usually yield desired biological activity which in this case, is inhibition of a-glucosidase in vitro assay. Active fractions, FEA8 was identified by thin layer chromatography using eluent chloroform : ethyl acetate: acetic acid (1:1:0.1), then sprayed with $1 \%$ ethanolic solution of aluminium chloride, observed under UV light $(366 \mathrm{~nm})$, while FM3 was identified by thin layer chromatography using eluent ethyl acetate: methanol (9:1), sprayed with 10\% methanolic solution of sulphuric acid and then be heated. Profile TLC of FEA8 show yellow and green fluorescence under UV light (366nm) and FM3 show violet spot (Figure 1). Flavonoids resulting blue, green or yellow fluorescence, which depends on the use of different spray reagents, ${ }^{13}$ while terpenoid compounds will form pink to purple or violet after being sprayed with $10 \%$ methanolic solution of sulphuric acid and be heated. ${ }^{14}$ This result does not rule out the possibility that the active fractions contain another phytoconstituents.

The previous studies show that twigs, stem bark, pericarp, and leaves G.hombroniana contain alkaloids, flavonoids, phenols, saponins, tannins, xanthones, benzophenones and terpenoids. ${ }^{15-18}$ Several studies about a-glucosidase inhibitors obtained from medicinal plants show that terpenes, alkaloids, flavonoids, and phenols have shown a-glucosidase inhibitory activity. ${ }^{19-21}$

This study can be confirmed by further experiments such as flavonoid, phenol, tannin, glycoside, terpenoid, alkaloid isolation from FEA8 and FM3 through preparative HPLC, preparative TLC, column chromatography or recrystallization and $\alpha$-glucosidase inhibitory activity assay of isolate that have been separated from other compounds.

\section{CONCLUSION}

Fraction 8 from the crude ethyl acetate extract of G.hombroniana leaves (FEA8) with eluent H/E 5:5 was separated as the most bioactive a-glucosidase inhibitor agent with the highest percentage inhibition compared with another fractions and extracts. The $\mathrm{IC}_{50}$ values of FEA8 fraction $(16.370 \mu \mathrm{g} / \mathrm{mL})$ were smaller than the $\mathrm{IC}_{50}$ of acarbose as a positive control $(39.534 \mu \mathrm{g} / \mathrm{mL})$, it exhibited higher potency of FEA8 compared to acarbose as positive control. However, further study is needed to isolate bioactive compound in this plant which is responsible for this activity.

\section{ACKNOWLEDGEMENT}

The authors thank PUPT Grant 2016 from Ministry of Research, Technology and Higher Education of The Republic of Indonesia for the opportunity research given. We would like to thank Laboratory of Phytochemistry 
and Pharmacognosy, Faculty of Pharmacy, University of Indonesia for providing extracts and for the research place.

\section{CONFLICT OF INTEREST}

The authors have no conflict of interest to declare.

\section{ABBREVIATIONS USED}

IDF: International Diabetes Federation ; WHO: World Health OOrrganization; TLC: Thin Layer Chromatography ; HPLC: High Performance Liquid Chromatography ; UV: Ultraviolet ; HbA1c: Haemoglobin A1c

\section{REFERENCE}

1. International Diabetes Federation. IDF Diabetes Atlas, 7th ed. Brussels, Belgium: International Diabetes Federation, 2015. http://www.diabetesatlas.org

2. Roglic G. WHO Global Report on Diabetes: A summary. Int J Non-Commun Dis 2016;1(1):3-8. https://doi.org/10.4103/2468-8827.184853.

3. Gu S, Shi J, Tang Z, Sawhney M, Hu H, Shi L, et al. Comparison of glucose lowering effect of metformin and acarbose in type 2 diabetes mellitus: A MetaAnalysis. PLoS One. 2015;10(5):e0126704. http://dx.doi.org/10.1371/journal. pone.0126704

4. Yang W, Liu J, Shan Z, Tian H, Zhou Z, Ji Q, et al. Acarbose compared with metformin as initial therapy in patients with newly diagnosed type 2 diabetes an open-label, non-inferiority randomised trial. Lancet Diabetes Endocrinol. 2014;2(1):46-55. http://dx.doi.org/10.1016/S2213-8587(13)70021-4.

5. Derosa G, Maffioli P. Efficacy and Safety Profile Evaluation of Acarbose Alone and in Association With Other Antidiabetic Drugs: A Systematic Review. Clin Ther. 2012;34(6):1221-36. http://dx.doi.org/10.1016/j.clinthera.2012.04.012.

6. Jindal A, Jindal M, Kaur M, Kumar R, Brar RS. Efficacy and safety of voglibose as an add-on triple drug in patients of type two diabetes mellitus uncontrolled with glimepiride and metformin in punjabi population. Indian J Basic Appl Med Res. 2014;3(3):111-6.

7. Kibiti CM, Afolayan AJ. Herbal therapy: A review of emerging pharmacological tools in the management of diabetes mellitus in Africa. Phcog Mag. 2015;11, Suppl S2:258-74. https://doi.org/10.4103/0973-1296.166046; PMid:26664014 PMCid:PMC4653336

8. Chan $\mathrm{CH}$, Ngoh GC, Yusoff R. A brief review on anti diabetic plants: Global distribution, active ingredients, extraction techniques and acting mechanisms. Phcog Rev. 2012;6:22-8. https://doi.org/10.4103/0973-7847.95854; PMid:22654401 PMCid:PMC3358964.

9. Zahratunnisa N, Elya B, Noviani A. Inhibition of Alpha-Glucosidase and Antioxi- dant Test of Stem Bark Extracts of GARCINIA fruticosa Lauterb. Pharmacogn J. 2017;9(2):273-5. https://doi.org/10.5530/pj.2017.2.46.

10. Elya B, Basah K, Munim A, YuliastutiW, Bangun A, Septiana EK, et al. Screening of $\alpha$-Glucosidase Inhibitory Activity from Some Plants of Apocynaceae, Clusiaceae, Euphorbiaceae, and Rubiaceae. J Biomed Biotechnol. 2012;2012:281078. http://dx.doi.org/10.1155/2012/281078.

11. Elya B, Handayani R, Sauriasari R, Azizahwati, Hasyyati US, Permana IT, et al. Antidiabetic Activity and Phytochemical Screening of Extracts from Indonesian Plants by Inhibition of Alpha Amylase, Alpha Glucosidase and Dipeptidyl Peptidase IV. Pak J Biol Sci. 2015;18(6):279-284. https://doi. org/10.3923/pjbs.2015.279.284.

12. Min SW, Han JS. Polyopes lancifolia Extract, a Potent $\alpha$-Glucosidase Inhibitor Alleviates Postprandial Hyperglycemia in Diabetic Mice. Prev Nutr Food Sci. 2014:19(1):5-9. https://dx.doi.org/10.3746/pnf.2014.19.1.005; PMid:24772403 PMCid:PMC3999809.

13. Wagner H, Bladt S. Plant Drug Analysis, A thin Layer Chromatography Atlas. 2nd ed. New York: Springer Verlag Berlin Heidlberg; 1996. p.197. PMCid:PMC1160836

14. Sharifa A, Jamaludin L, Kiong S, Chia S, Osman K. Anti-Urolithiatic Terpenoid Compound from Plantago major Linn. (Ekor Anjing). Sains Malaysiana. 2012:41(1),33-9.

15. Dyary H, Arifah A, Sharma R, Rasedee A, Aspollah M, Zakaria Z, et al. Antitrypanosomal screening and cytotoxic effects of selected medicinal plants. Trop Biomed. 2014;31(1):89-96. PMid:24862048.

16. Marlin S, Elya B, Katrin. Antioxidant Activity and Lipoxygenase Enzyme Inhibition Assay with Total Flavonoid Content from Garcinia hombroniana Pierre Leaves. Pharmacogn J. 2017; 9(2):267-72. https://doi.org/10.5530/pj.2017.2.45.

17. Listiyani A, Elya B, Puspitasari N. Antioxidant Activity and Lipoxygenase Enzyme Inhibitory Assay with Total Flavonoids Content from Garcinia hombroniana Pierre Stem Bark Extract. Pharmacogn J. 2017;9(2):276-9. https://doi. org/10.5530/pj.2017.2.47.

18. Jamila N, Khairuddean M, Khan SN. Phytochemicals from the Bark of Garcinia hombroniana and Their Biological Activities. Rec Nat Prod. 2014:8(3),312-6.

19. Yin Z, Zhang W, Feng F, Zhang Y, Kang W. $\alpha$-Glucosidase inhibitors isolated from medicinal plants. Food Sci Hum Wellness. 2015;3(3-4):136-174. http://dx.doi. org/10.1016/j.fshw.2014.11.003.

20. Ikarashi N, Takeda R, Ito K, Ochiai W, Sugiyama K. The Inhibition of Lipase and Glucosidase Activities by Acacia Polyphenol. Evid Based Complement Alternat Med. 2011;2011:272075. https://dx.doi.org/10.1093/ecam/neq043.

21. Yilmazer-Musa M, Griffith A, Michels A, Schneider E, Frei B. Inhibition of $\alpha$-Amylase and $\alpha$-Glucosidase Activity by Tea and Grape Seed Extracts and their Constituent Catechins. J Agric Food Chem. 2015;60(36):8924-9. https://doi. org/10.1021/jf301147; PMid:22697360 PMCid:PMC4356113.

\section{GRAPHICAL ABSTRACT}

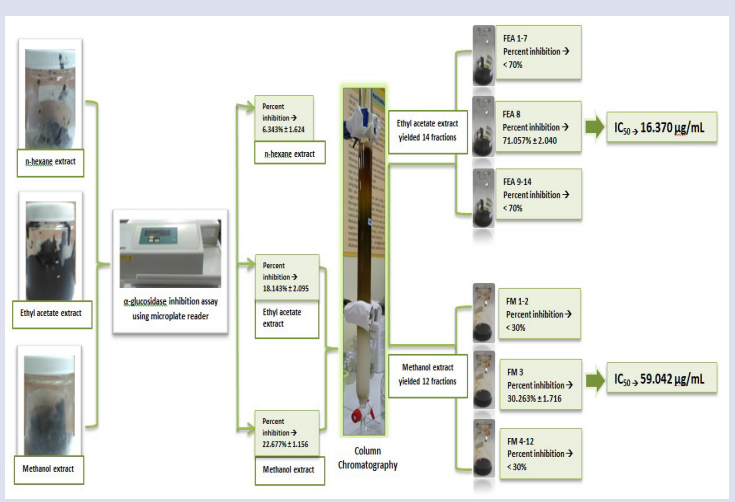

\section{SUMMARY}

- The most active fraction from extract of G.hombroniana was separated and tested for $\alpha$-glucosidase inhibition activity.

- Extracts' test results of $\alpha$-glucosidase inhibition show that percent inhibition of n-hexane extract of G.hombroniana is the lowest, so fractionation performed only on ethyl acetate and methanol extract of G.hombroniana.

- Fractionation of ethyl acetate and methanol extract of G.hombroniana yielded 14 and 12 fractions, respectively.

- Two fractions with the higher percent inhibition compared to other factions are fraction 8 from ethyl acetate extract (FEA8) and fraction 3 from methanol extract (FM3) with percent inhibition $71.057 \% \pm 2.040$ and $30.263 \% \pm 1.716$, respectively.

- The highest inhibitory activity of samples was obtained from FEA 8 fraction with $I C_{50}$ value $16.370 \mathrm{ug} / \mathrm{mL}$ was much smaller than the $I C_{50}$ of acarbose as a positive control $\left(I C_{50}\right.$ acarbose $\left.=39.534 \mu \mathrm{g} / \mathrm{mL}\right)$

\section{ABOUT AUTHORS}

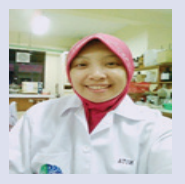

Nita Triadisti: Is a master student at the Faculty of Pharmacy, University of Indonesia. Her master research focused on the fractionation, isolation, structure elusidation of natural products and bioassay: $\alpha$-glucosidase inhibition assay and antioxidant assay. 
Berna Elya: Is Professor at the Faculty of Pharmacy, University of Indonesia. She is Head of Laboratory of Phytochemistry and Pharmacognosy. Has expertise in the area of Pharmacognosy and Phytochemistry of Natural Products, working mainly in: Natural Product Isolation and Bioassay.

Rani Sauriasari: Is Lecturer and Researcher at the Faculty of Pharmacy, University of Indonesia. She has expertise in Diabetes, Pharmacoepidemiology, and Bioanalysis.

Cite this article:Triadisti N, Sauriasari R, Elya B. Fractionation and $\alpha$-glucosidase Inhibitory Activity of Fractions from Garcinia hombroniana Pierre Leaves Extracts. Pharmacog J. 2017;9(4):488-92. 